\title{
Unidirectional heterologous receptor desensitization between both the fMLP and C5a receptor and the IL-8 receptor
}

\author{
"R. Alexander Blackwood, †Kaija T. Hartiala, "Ely E. Kwoh, "Amy T. Transue, "Ruth C. Brower \\ 'Department of Pediatrics, Division of Infectious Diseases, University of Michigan, Ann Arbor, and ${ }^{\dagger}$ Department of \\ Pediatrics, University of Turku, Turku, Finland
}

\begin{abstract}
During inflammation neutrophils receive multiple signals that are integrated, allowing a single modified response. One mechanism for this discrimination is receptor desensitization, a process whereby ligand-receptor binding is disassociated from cell activation. We examined the effect of heterologous receptor desensitization on neutrophil chemotaxis, calcium mobilization, and arachidonic acid production, using interleukin-8 (IL-8), C5a, and N-formylmethionyl-leucyl-phenylalanine (fMLP). We observed reciprocal inhibition with respect to chemotaxis. We demonstrated that homologous desensitization, with respect to the mobilization of intracellular calcium stores, lasted approximately 15 min. Heterologous desensitization between the fMLP receptor and the $\mathrm{C5}$ a receptor was reciprocal; either stimulant would diminish the cells' response to stimulation by the other for approximately 3-5 min. However, we observed a unidirectional heterologous desensitization of the IL-8 receptor by both the fMLP and the $\mathrm{C5a}$ receptor. This unidirectional heterologous desensitization was observed with respect to both calcium mobilization and arachidonic acid production (i.e., prestimulation of the IL-8 receptor had no effect on subsequent stimulation by either fMLP or C5a). J. Leukoc. Biol. 60: 88-93; 1996.
\end{abstract}

Key Words: desensitization $\cdot$ neutrophils $\cdot$ chemotaxis $\cdot$ arachidonic acid · ineracellular calcium

\section{INTRODUCTION}

Inflammation results in the release of a variety of chemotactic and stimulatory factors from a number of different cell types. Polymorphonuclear leukocytes (PMNs), therefore, must differentiate these signals and be capable of modifying their responses when confronted with multiple stimulatory and inhibitory signals simultaneously. Prestimulation of PMNs with C5a or AMLP diminishes their chemotactic response not only to the initial stimulus (homologous desensitization) but also to the reciprocal stimulus (heterologous desensitization) $[1,2]$. Not only is chemotaxis affected, but PMNs desensitized by prestimulation also fail to generate $\mathrm{O}_{2}{ }^{-}$and release granule marker enzymes [3, 4]. Homologous receptor desensitization is known to occur for many receptors (fMLP, C5a) through receptor internalization. However, Yagawa and co-workers $[5,6]$ found no inhibition of AMLP and wheat germ agglutinin binding following immune complex-mediated desensitization. Thus receptor recycling is not the mechanism of heterologous desensitization in this case.

Heterologous receptor desensitization appears to be specific for each receptor. Didsbury and co-workers [7] transfected human kidney cells with the C5a and fMLP receptors. Both receptors were able to initiate phospholipase C (PLC) activation as determined by the rise in intracellular $\mathrm{Ca}^{2+}$. When the $\mathrm{C} 5 \mathrm{a}$ and $\mathrm{fMLP}$ receptors were cotransfected they exhibited reciprocal heterologous receptor desensitization; however, neither affected, nor was affected by, stimulation of the native $\alpha_{1}$-adrenergic receptor.

We examined the effect of heterologous receptor desensitization on PMN chemotaxis using three chemotactic peptides, IL-8, C5a, and fMLP. We observed that chemotaxis to a gradient stimulus was inhibited by a nongradient stimulus in a reciprocal fashion. In an attempt to delineate the location of the interruption in signal transduction, we examined two early events in PMN activation, intracellular calcium mobilization and arachidonic acid release. As expected, homologous receptor desensitization resulted in inhibition of calcium mobilization and arachidonic acid release. This inhibition lasted longer than $15 \mathrm{~min}$. We also observed reciprocal heterologous desensitization between the IMLP receptor and the C5a receptor. However, we observed nonreciprocal heterologous desensitization between the IL-8 receptor and both the C5a and MLP receptors, with respect to both calcium mobilization and arachidonic acid release.

Abbreviations: BSA, bovine serum albumin; fMLP, $N$-formylmethionyl-leucyl-phenylalanine; IL-8, interleukin-8; PBS, phosphatebuffered saline; PLA 2 , phospholipase $A_{2}$; PLC, phospholipase C; PMN, polymorphonuclear leukocyte; TCR, $T$ cell receptor.

Reprint requests: R. Alexander Blackwood, University of Michigan Medical Center, 1500 E. Medical Center Drive, Ann Arbor, MI 481090224.

Received November 2, 1995; revised Murch 11, 1996; acceplod March $12,1996$. 
supernatants were collected and counted in a scintillation counter. Results were expressed as percent of total arachidonic acid released.

\section{Isolation and preparation of human neutrophils}

Neutrophils were obtained from fresh human blood using the method of Boyum [8]. ACD, anticoagulated blood was obtained from healthy donors and sedimented with $6 \%$ dextran $(0.9 \% \mathrm{NaCl})$. Red blood cells were removed by hypotonic lysis, and neutrophils were isolated by density gradient centrifugation on a $10 \%$ Ficoll-Hypaque cushion. The resulting cells (98\% neutrophils) were washed three times in phosphatebuffered saline (PBS) and transferred to the appropriate buffer for further studies.

\section{Chemotaxis assay}

The chemotaxis assays were performed in multiwell microchemotaxis chambers (Neuro Probe, Cabin John, MD) [9]. Human neutrophils were suspended in Hanks' balanced salt solution with $2 \%$ bovine serum albumin (BSA) at $4 \times 10^{6}$ cells $/ \mathrm{mL}$. For desensitization, the neutrophils were mixed with the desensitizing chemoattractant, $5 \times 10^{-8} \mathrm{M}$ MLP or $5 \times 10^{-9} \mathrm{M} \mathrm{C} 5 \mathrm{a}$ or IL-8, and placed immediately in the upper chemotaxis chamber. The lower chamber contained an equal concentration of the desensitizing chemoattractant and the chemoattractant of interest, also at $5 \times 10^{-8} \mathrm{M}$ fMLP or $5 \times 10^{-9} \mathrm{M} \mathrm{C5a}$ or IL-8. Random migration was determined using buffer alone as a control. The chambers were separated by a $200-\mu \mathrm{m}$-thick nitrocellulose filter, pore size $3 \mu \mathrm{m}$. The neutrophils were allowed to migrate for $13 \mathrm{~min}$ at $37^{\circ} \mathrm{C}$. The filters were then fixed, stained with hematoxylin-eosin, and dehydrated and clarified with xylene. Migration of the leading front of neutrophils was assessed microscopically and expressed in micrometers. Net migration was the migration toward chemoattractant minus the random migration. Results were expressed as percent of control migration for each stimuli. Each experiment was performed in triplicate, and five fields per filter were examined.

\section{Measurements of intracellular $\mathrm{Ca}^{2+}$}

Intracellular calcium determinations were performed using the fluorescent calcium indicator fluo-3 [10]. Purified neutrophils were suspended $\left(1 \times 10^{7} / \mathrm{mL}\right)$ in buffer D (10 mM HEPES, $145 \mathrm{mM} \mathrm{NaCl}, 5 \mathrm{mM} \mathrm{KCl}, 1$ $\mathrm{mM} \mathrm{MgCl}, 10 \mathrm{mM}$ glucose, $1 \mathrm{mM} \mathrm{CaCl}$, and $1 \% \mathrm{BSA} ; \mathrm{pH} \mathrm{7.4)} \mathrm{and}$ incubated with $2 \mu \mathrm{M}$ fluo-3 $\mathrm{AM}$ for $30 \mathrm{~min}$ at $37^{\circ} \mathrm{C}$. The cells were washed three times with buffer $D$ and maintained at $4^{\circ} \mathrm{C}$ until 3-5 min prior to use. Three to five minutes before each calcium determination, $1-\mathrm{mL}$ aliquots of cells were brought to $37^{\circ} \mathrm{C}$. Neutrophils $(0.9 \mathrm{~mL}$ at 1 $\times 10^{7} / \mathrm{mL}$ ) were placed in an SLM 8000 spectrofluorometer (excitation wavelength $505 \mathrm{~nm}$, emission wavelength $530 \mathrm{~nm}$ ) and baseline was allowed to stabilize for $30 \mathrm{~s}$. Varying concentrations of chemoattractants were added $(0.1 \mathrm{~mL})$ and fluorescence was monitored continuously for 150-180 s.

For assays examining the duration of either heterologous or homologous desensitization, five identical tubes were incubated and stimulated with desensitizing agent simultaneously. The initial sample was challenged with the second stimulating agent $150 \mathrm{~s}$ following the first agent and monitored continuously for $150 \mathrm{~s}$. Subsequent tubes were stimulated and monitored every $150 \mathrm{~s}$ to determine the duration of desensitization.

\section{Determination of arachidonic acid release}

Purified PMNs $\left(5 \times 10^{7}\right.$ cells $\left./ \mathrm{mL}\right)$ were incubated with $100 \mu \mathrm{Ci}\left({ }^{3} \mathrm{H}\right)$ acid in buffer $D$ containing $1 \%$ fatty acid-free BSA for $45 \mathrm{~min}$ at $37^{\circ} \mathrm{C}$. Arachidonic acid was readily taken up by cells and incorporated into membrane phospholipids [11]. The cells were then washed three times and suspended in buffer $\mathrm{D}\left(10^{7}\right.$ cells $\left./ \mathrm{mL}\right)$ containing $1 \%$ regular BSA and $0.01 \mathrm{mM}$ unlabeled arachidonic acid, to remove unincorporated labels. Cells were stimulated for $5 \mathrm{~min}$ with the desensitizing stimulant and allowed to incubate for $7 \mathrm{~min}$ at $37^{\circ} \mathrm{C}$. PMNs were then challenged with the second stimulus, $7 \mathrm{~min}, 37^{\circ} \mathrm{C}$. Following centrifugation, the

\section{RESULTS}

Neutrophils are known to migrate along a concentration gradient to a variety of chemotactic agents. Although most in vitro studies examining neutrophil chemotaxis are interested in specific responses to individual chemotactic agents, in vivo neutrophils encounter multiple signals simultaneously. Neutrophils must therefore process these multiple signals and elicit a single unified response. To better understand how neutrophils interpret multiple signals, we examined the effect of dual stimulation on PMN chemotaxis using three different chemotactic agents, fMLP, IL-8, and C5a. Human PMNs were simultaneously stimulated with two chemotactic agents, one as a gradient and the other at a static (nongradient) concentration. Static concentrations of both FMLP and C5a resulted in a statistically significant inhibition of the migration of human neutrophils to IL-8 (Fig. 1A). Likewise, fMLP and IL-8 inhibited chemotaxis toward C5a (Fig. 1C). IL-8 and C5a also resulted in a decrease in the migration of human neutrophils toward IMLP, even though the inhibition observed with C5a was not statistically significant (Fig. 1B). Thus a static concentration of a chemoattractant, such as IL-8, fMLP, or C5a, inhibits chemotaxis along a concentration gradient.

To determine whether the inhibition observed with chemotaxis correlated with receptor desensitization, we examined the effect of dual stimulation on intracellular calcium mobilization. Isolated PMNs were loaded with the calcium-sensitive fluorescent dye fluo-3 and stimulated with varying concentrations of $\mathrm{MLP}, \mathrm{C5a}$, or IL-8. Intra-

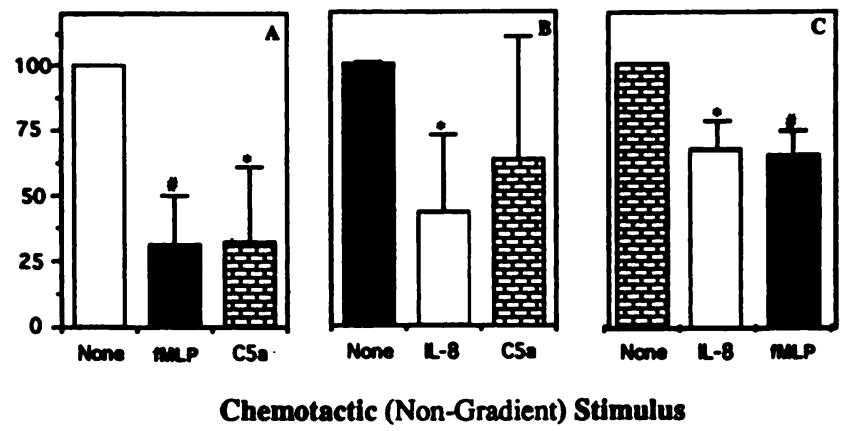

Fig. 1. Reciprocal inhibition of PMN chemotaxis by IL-8, C5a, and MLP. Isolated human PMNs were mixed with the desensitizing stimulus $(5 \times$ $10^{-8} \mathrm{M}$ IMLP or $5 \times 10^{-9} \mathrm{M}$ C5a or IL -8 ) immediately prior to being placed in the upper well of a chemotaxis chamber. The lower chamber contained an equal concentration of the desensitizing agent as well as the chemoattractant of interest. Net migration was determined (migration toward the chemoattractant minus random migration) microscopically, and results were expressed as a percentage of the control migration. Results are the mean and standard deviation of three separate experiments. (A) $5 \times 10^{-9}$ $\mathrm{M}$ IL-8 is the gradient stimulus; (B) $5 \times 10^{-8} \mathrm{M}$ MLP; (C) $5 \times 10^{-9} \mathrm{M}$ C5a. $* P \S 0.05 ; \# P<0.01$. 
cellular calcium concentrations were monitored continuously on an SLM 8000 spectrofluorometer for $150 \mathrm{~s}$. Cells stimulated with fMLP, C5a, or IL-8 all exhibited normal calcium transients. Prestimulation with either fMLP or C5a inhibited subsequent calcium transients to IL-8 given 150 s later (Fig. 2A and C). However, prestimulation with IL-8 had no effect on subsequent calcium transients elicited by either $\mathrm{AMLP}$ or C5a (Fig. 2B and D). The duration and the extent of IL-8 desensitization induced by fMLP and C5a were different. fMLP virtually abolished calcium transients in response to IL-8 for 12.5 to $15 \mathrm{~min}$, while PMNs prestimulated with C5a showed a marked decrease in IL-8 responsiveness that was gradually restored with time, although normal levels were usually not reached at 12.5 to 15 min (Fig. 3).

Reciprocal heterologous desensitization was observed between the fMLP and C5a receptors with respect to calcium mobilization (Fig. 4). Prestimulation of either receptor resulted in decreased responsiveness to stimulation by the other receptor. The time course of desensitization lasted 5 to $7.5 \mathrm{~min}$.

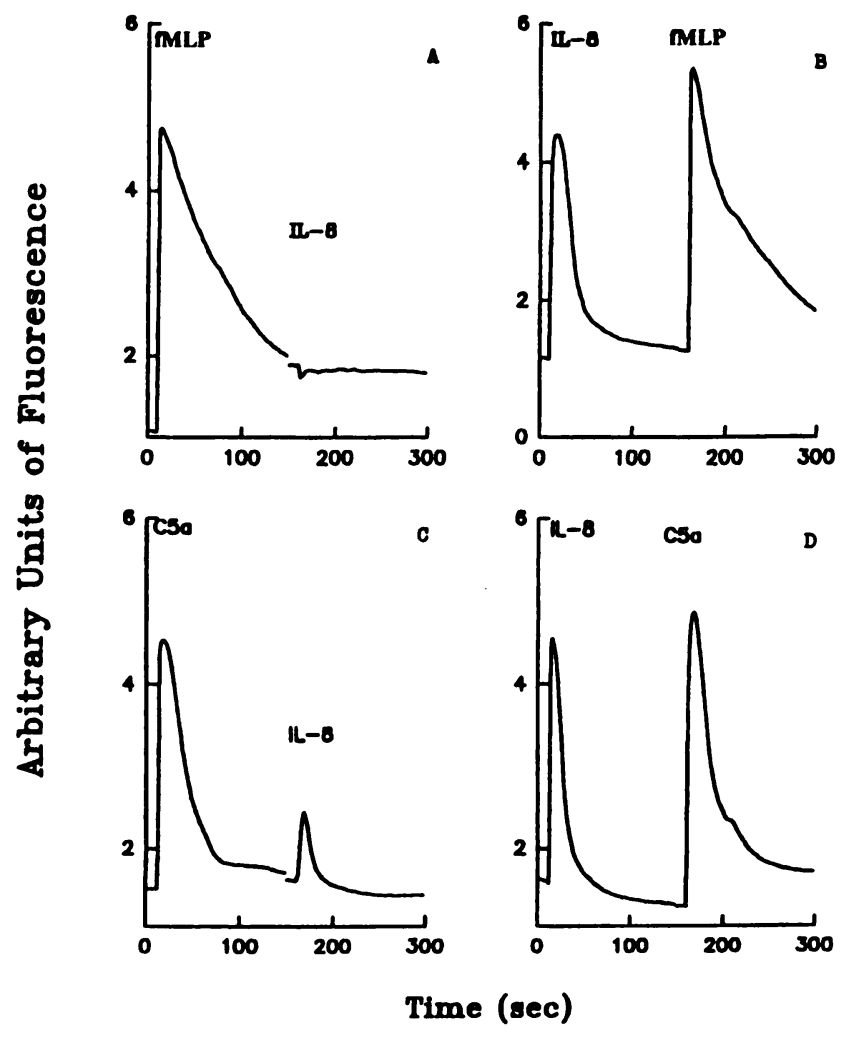

Fig. 2. Nonreciprocal Inhibition of IL-8-stimulated calcium mobilization by C5a and fMLP. Isolated PMNs $\left(0.9 \times 10^{7} / \mathrm{mL}\right)$, loaded with the calcium-sensitive fluorescent dye fluo-3, were stimulated with $10^{-8} \mathrm{M}$ fMLP (A), C5a (C), or IL-8 (B, D). Intracellular calcium concentrations were monitored continuously for 150 s on an SLM 8000 spectrofluorometer (excitation $505 \mathrm{~nm}$, emission $530 \mathrm{~nm}$ ). The cells were then challenged with $10^{-8} \mathrm{M}$ IL-8 (A, C), $\mathrm{FMLP}(\mathrm{B})$, or C5a (D) and monitored an additional $150 \mathrm{~s}$. Results are representative tracings from at least three separate donors.

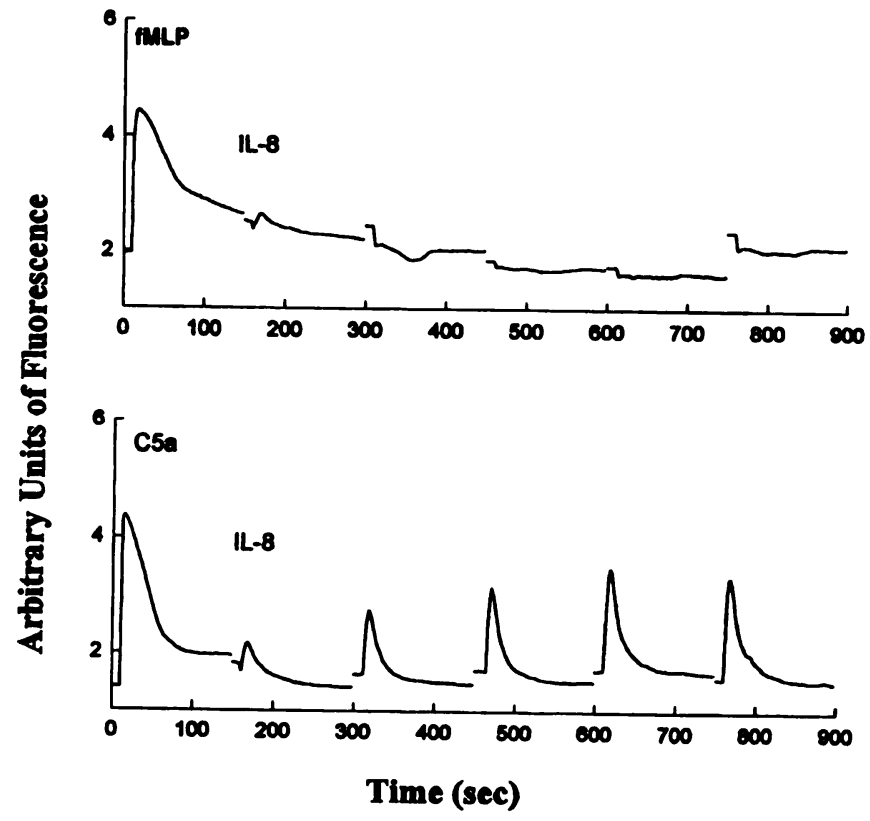

After Initial Stimulus

Fig. 3. Duration of AMLP- and C5a-induced desensitization of IL-8 receptor. Five aliquots of fluo 3-labeled PMNs were stimulated simultaneously with $10^{-8} \mathrm{M}$ fMLP or C5a (top and bottom, respectively). At 150-8 intervals an aliquot of cells was challenged with $10^{-8} \mathrm{M}$ IL-8. Intracellular calcium concentrations were monitored continuously on an SLM 8000 spectrofluorometer. Results are representative tracings from at least three separate experiments from two different donors.

Desensitization was dependent on the concentrations of both the initial and secondary stimulus. Although decreasing concentrations of $\mathrm{fMLP}$ between $10^{-7}$ and $10^{-9}$ gave the same rise in intracellular calcium, they exhibited decreasing ability to desensitize and block subsequent calcium transients induced by IL-8 (Fig. 5A-D). Similar results were observed with C5a (data not shown).

Homologous receptor desensitization was observed with respect to stimulation of the FMLP, IL-8, and C5a (data not shown) receptors. Prestimulation with any of the chemoattractants examined inhibited calcium transients to subsequent rechallenge with the same stimuli. This desensitization was still present 12.5 to 15 min following the initial stimuli (data not shown).

To further localize where in the signal transduction pathway desensitization occurs, we examined the effect of receptor desensitization on arachidonic acid release from human neutrophils. PMNs whose membrane phospholipids were prelabeled with $\left[{ }^{3} \mathrm{H}\right]$ arachidonic acid were stimulated with IL-8, C5a, or fMLP 7 min prior to rechallenge with IL-8, C5a, or fMLP, and the percent of total arachidonic acid released was determined. Arachidonic acid release due to stimulation by IL-8 was inhibited heterologously by prestimulation with $\mathrm{AMLP}$ and C5a and homologously by IL-8 prestimulation (Fig. 6A). Only homologous desensitization was observed for the C5a receptor (Fig. 6B). There was no significant effect of desensitization on arachidonic 


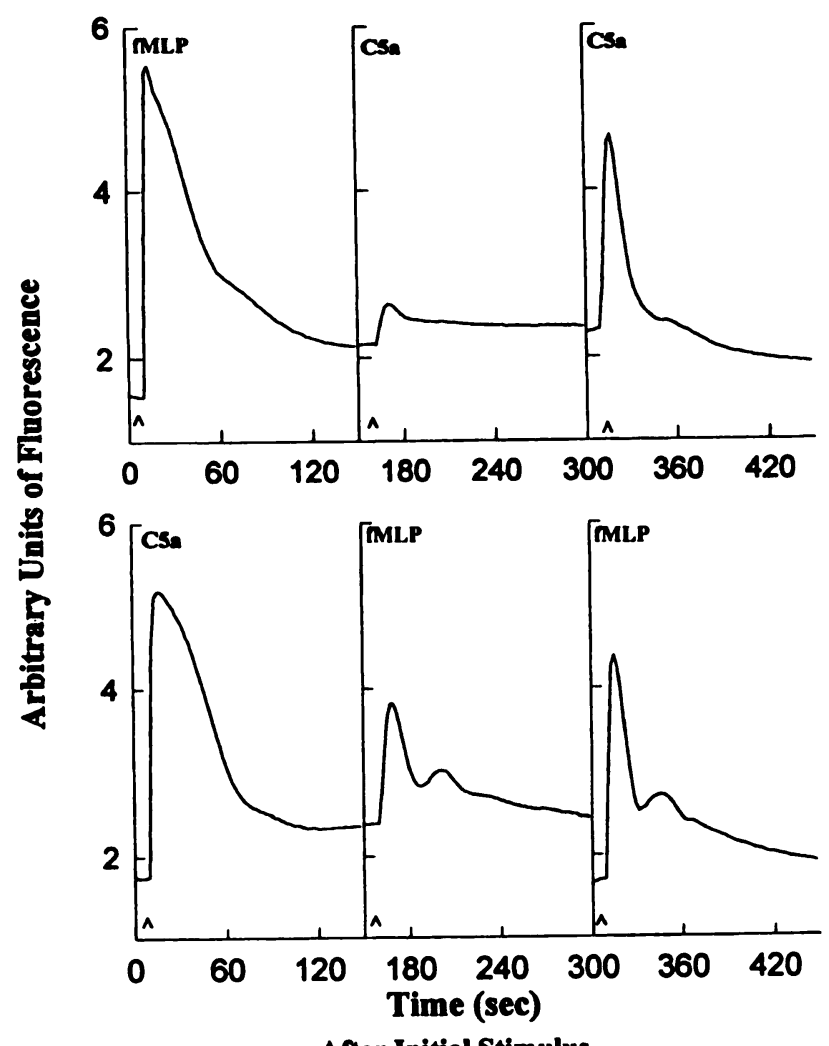

After Initial Stimulus

Fig. 4. Reciprocal inhibition of calcium mobilization induced by IMLP and C5a. Isolated PMNs were stimulated with $10^{-8} \mathrm{M}$ fMLP (top) or C5a (bottom). The cells were rechallenged 150 or $300 \mathrm{~s}$ following the initial stimulus with $10^{-8} \mathrm{M} \mathrm{C5a}$ (top) or MLP (bottom). Intracellular calcium concentrations were monitored continuously for 450 s on an SLM 8000 spectrofluorometer. Results are representative tracings from two separate donors.

acid production with respect to the $\mathrm{FLP}$ receptor (Fig. 6C).

\section{DISCUSSION}

We examined the effect of heterologous receptor desensitization on PMN chemotaxis, calcium mobilization, and arachidonic acid production, using three chemotactic peptides: IL-8, C5a, and FMLP. We observed that a nongradient stimulus inhibited chemotaxis to a gradient stimulus in a reciprocal fashion. All three chemotactic peptides examined inhibited chemotaxis to the other stimuli.

In an attempt to localize where, during the signal transduction process, desensitization occurs, we examined intracellular calcium mobilization and arachidonic acid production in PMNs stimulated sequentially with different chemotactic peptides. We observed that the inhibition of chemotaxis was independent of calcium mobilization and arachidonic acid production. There was a unidirectional inhibition of both calcium mobilization and arachidonic acid production between both the AMLP and C5a receptors and the IL-8 receptor. Thus, IL-8 inhibited chemotaxis to both C5a and fMLP receptor stimulation despite normal generation of calcium transients and arachidonic acid production. Previous reports indicated that chemotaxis was not a calcium-dependent cellular function [12]. However, these studies also indicated that it was independent of the activation of phospholipase $A_{2}$ and the generation of arachidonic acid.

Norgauer and co-workers [13] have demonstrated that while both Il-8 and fMLP activate the mobilization of $\mathrm{Ca}^{2+}$ from intracellular stores, only FMLP triggers the secondary influx from the extracellular space. Interestingly, this correlated with differences in the metabolism of phosphorylated phosphoinositides as well as the formation of phosphatidic acid. Because phospholipid metabolism is an integral part of PMN activation, different levels or states of activation may represent one mechanism for the control of different neutrophil functions and may at least partially explain why although IL-8 is a potent chemoattractant it is a weak activator of the respiratory burst.

Unlike homologous desensitization, heterologous desensitization is not thought to be secondary to receptor recycling. Yagawa and co-workers $[5,6]$ described normal fMLP binding despite immune complex-mediated desensitization. Heterologous desensitization also appears to be specific for each receptor. Didsbury and co-workers [7] showed that although transfected fMLP and C5a receptors

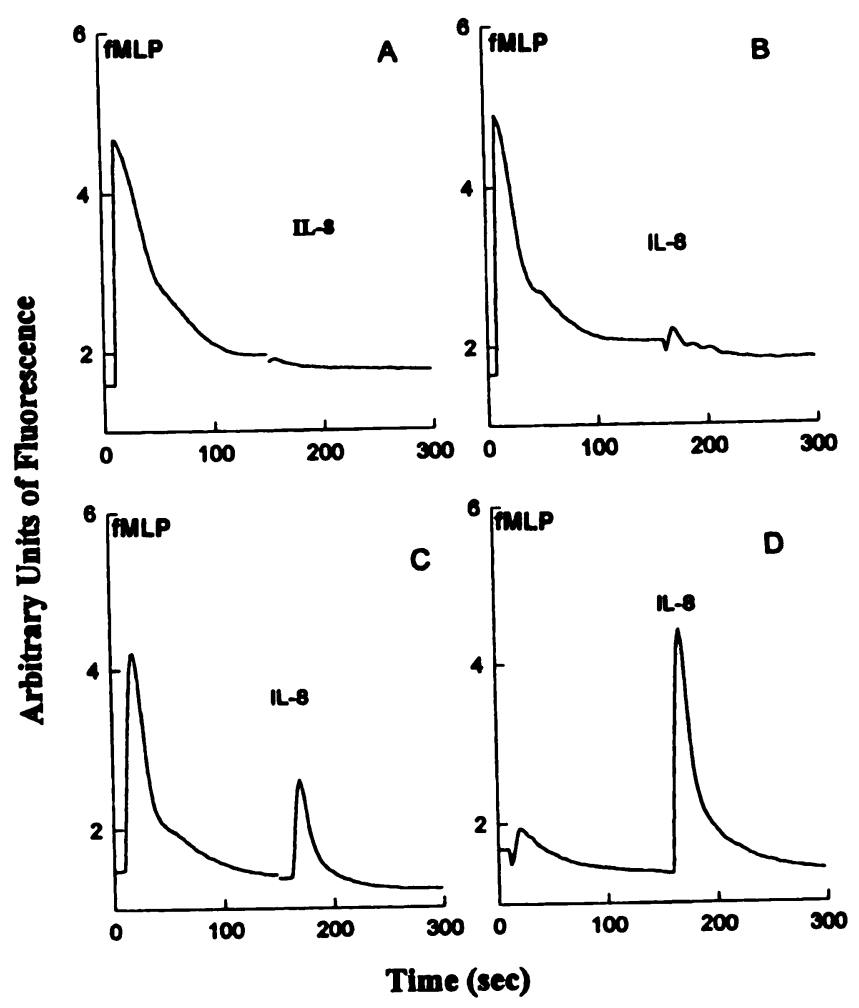

Fig. 5. Concentration-dependent heterologous desensitization between fMLP and IL-8 receptors. Fluo 3-labeled PMNs were stimulated with decreasing concentrations of $\mathrm{MLP}\left(\mathrm{A}, 10^{-7} \mathrm{M} ; \mathrm{B}, 10^{-8} \mathrm{M} ; \mathrm{C}, 10^{-9} \mathrm{M} ; \mathrm{D}\right.$, $10^{-10}-\mathrm{MiF} 150$ s prior to stimulation with $10^{-8} \mathrm{M}$ IL-8. Intracellular calcium concentrations were monitored continuously. Results are representative fracings from at least three separate donors. 

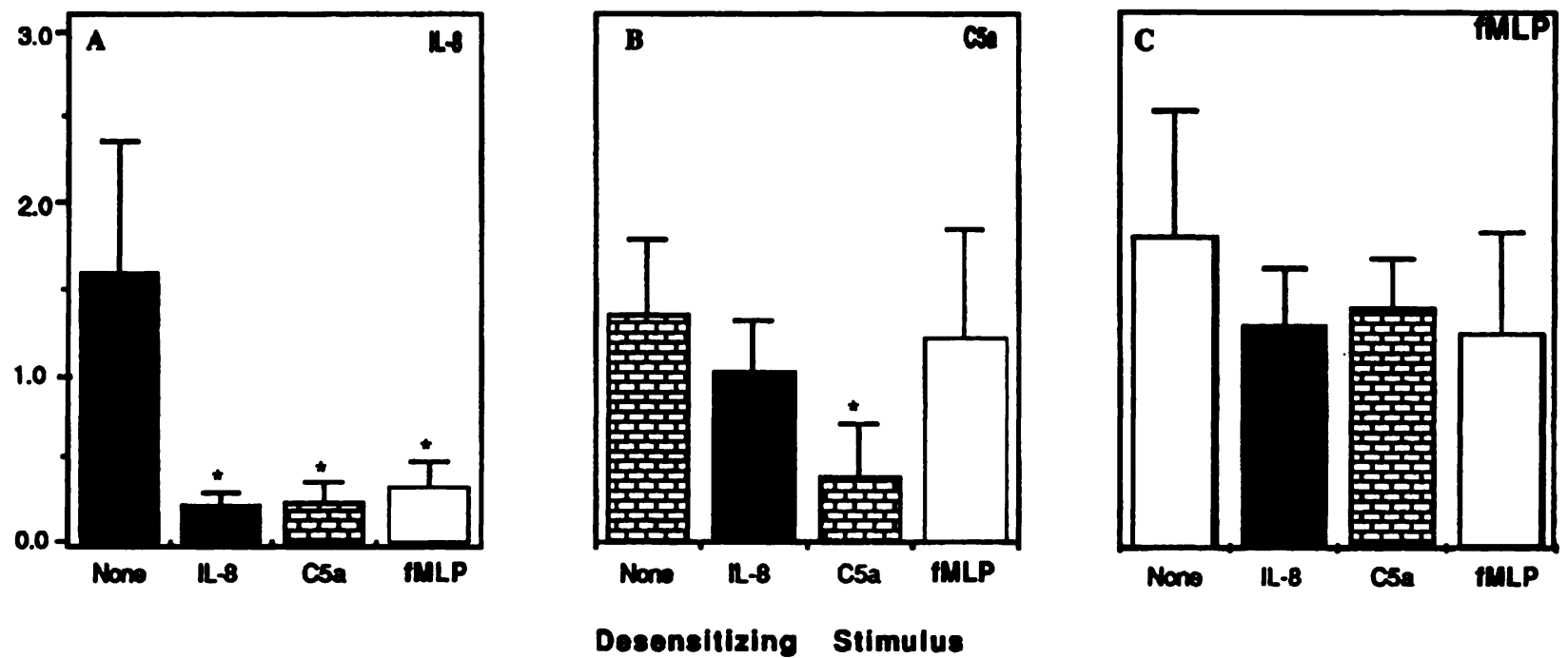

Desensitizing Stimulus

Fig. 6. Effect of desensitization on arachidonic acid production in human neutrophils. Human neutrophils were incubated with $\left[{ }^{3} \mathrm{H}\right]$ arachidonic acid to label membrane phospholipids. The cells were then stimulated with $10^{-8} \mathrm{M}$ IL-8, IMLP, or C5a (desensitizing stimulus) and incubated for 7 min prior to subsequent challenge with $10^{-8} \mathrm{M}$ IL-8, C5a, or fMLP (secondary stimulus). Following a 7-min incubation, the cells were pelleted and the supernatants were assayed for the release of $\left[{ }^{3} \mathrm{H}\right]$ arachidonic acid. Secondary stimulus: A, IL-8; B, IMLP; C, C5a. Results are the mean and standard deviation of at least five experiments done in duplicate. ${ }^{\circ} P<0.05$.

cross-desensitized each other, both were unaffected by stimulation of a native receptor from kidney cells. Because signal transduction, as measured by $\mathrm{Ca}^{2+}$ transients, was maintained across cell types, certain common components must exist. Thus receptor-receptor distinction must exist with respect to desensitization. Our results further demonstrate this phenomenon, indicating that a hierarchy may actually exist between receptors. Both arachidonic acid release and calcium mobilization in response to IL-8 stimulation were inhibited by previous stimulation with either IMLP or C5a. Desensitization, with respect to calcium mobilization, was more profound following fMLP stimulation as compared with C5a. Furthermore IL-8 showed no desensitization of either the fMLP or C5a receptor.

A similar nonreciprocal heterologous desensitization has been described with the CD3-T cell receptor (TCR) complex and the pertussis toxin receptor [14]. The authors propose that signal transduction through the pertussis toxin receptor is dependent on secondary stimulation of CD3TCR complex distal to its antigen binding domain. Thus, regulation of the CD3-TCR complex would also regulate the pertussis toxin receptor. This is not the case for the fMLP and C5a receptors, because regulation would have to be through both receptors simultaneously and be distinct from the control pathway for chemotaxis. Heterologous desensitization for the fMLP, C5a, and IL-8 receptors is thought to involve receptor phosphorylation via second messanger-activated kinases, such as protein kinases A and C [15-20]. Interestingly, Metzner et al. [21] have demonstrated that IL-8 actually up-regulates IMLP-dependent generation of superoxide anion presumably through the increased expression of $\mathrm{MMLP}$ receptors.

We demonstrated that homologous desensitization, with respect to the mobilization of intracellular calcium stores, lasted more than 12.5-15 min. These finding are consistant with the findings that ligand-receptor binding results in the internalization of the receptor and a decrease in surface receptor numbers $[22,23]$. As expected, we also observed homologous desensitization with respect to arachidonic acid production for IL-8 and C5a. Although we were unable to demonstrate homologous desensitization for the fMLP receptor, we suspect that this may be secondary to the constraints of our studies. As with other measures of PMN activation, the time course and total release of arachidonic acid in response to fMLP were greater than those observed for C5a and IL-8 (data not shown).

Confirming reciprocal heterologous desensitization between the AMLP receptor and the C5a receptor, with respect to intracellular $\mathrm{Ca}^{2+}$ transients (i.e., either stimulant would diminish the cells' response to stimulation by the other for approximately 3-5 $\mathrm{min}$ ), we took advantage of the difference in the time course of desensitization between C5a, fMLP, and IL-8. We examinined the effect of dual stimulation on the activation of PLA $\mathrm{PL}_{2}$ and the generation of arachidonic acid. PLA 2 metabolism has been implicated in both the respiratory burst and PMN degranulation [24-27]. As predicted, there was a correlation between desensitization of intracellular $\mathrm{Ca}^{2+}$ transients and desensitization of arachidonic acid release. We chose a time interval between stimuli of $7 \mathrm{~min}$. At this interval both fMLP and C5a desensitize IL-8-mediated activation of PLC and PLA 
Reciprocal desensitization between the FMLP and C5a receptors lasted only 3 to $5 \mathrm{~min}$ with respect to the rise in intracellular $\mathrm{Ca}^{2+}$. In conjunction with this, no desensitization was observed between these receptors with respect to arachidonic acid generation. IL-8, on the other hand, exhibited only homologous desensitization with respect to both PLC and PLA 2 activation.

Homologous receptor desensitization is known to be linked to receptor availability. However, the mechanism of heterologous desensitization is linked to receptor phosphorylation [15-17]. Our chemotaxis data indicated that the inhibition was reciprocal. Yet, two separate markers of early PMN activation, intracellular calcium concentration and arachidonic acid release, demonstrated nonreciprocal desensitization. Desensitization is also concentration dependent for both primary and secondary stimulants, indicating that while the receptor's availability is unaffected, its affinity or ability to transduce the signal may be altered. As both PLA 2 and PLC are activated through separate G proteins, one potential level of control for desensitization would be proximal to their activation. Tomhave and coworkers [28] have demonstrated that desensitization is also proximal to phospholipase $D$ activation. Thus heterologous desensitization probably involves many levels of control and may very well be distinct for each receptor pair.

\section{REFERENCES}

1. Dallegri, F., Lanzi, G., Patrone, F. (1980) Evidence for a reversible functional state of neutrophil chemotactic deactivation. Ins. Arch. Allergy Appl. Immunol. 63, 330-337.

2. Nelson, R.D., McCormack, R.T., Fiegel, V.D., Simmons, R. L. (1978) Chemotactic deactivation of human neutrophils: evidence for nonspecific and specific components. Infect. Immun. 22, 441-444

3. Henson, P.M., Zanolari, B., Schwartzman, N.A., Hong, S.R. (1978) Intracellular control of human neutrophil secretion. I. C5a-induced stimulus-specific desensitization and the effects of cytochalasin B.J. Immunol. 121,851-855.

4. Henson, P.M., Zanolari, B., Schwartzman, N. A. (1981) Intracellular control of human neutrophil secretion. II. Stimulus specificity of desensitization induced by six different soluble and particulate stimuli. J. Immunol. 127, $754-759$.

5. Yagawa, K., Kaku, M., Ichinose, Y., Aida, Y., Tomoda, A. (1985) Fc receptor-mediated desensitization of superoxide $\left(0_{2}\right)$ generation response of guinea-pig macrophages and polymorphonuclear leucocytes. Immunology $55,629-638$.

6. Yagawa, K., Hayashi, S., Nakanishi, M., Aso, H., Ogata, K., Maruyama, M., Ichinose, Y., Shigematsu, N. (1987) Restoration of Fc receptor-mediated desensitization of superoxide generation in human PMN by PMA. Int. J. Immunopharmacol. 9, 497-501.

7. Didsbury, J.R., Uhing, R.J., Tomhace, E., Gerard, N., Snyderman, R. (1991) Receptor class desensitization of leukocyte chemoattractant receptor. Proc. Natl. Acad. Sci. USA 88, $11564-11568$.

8. Boyum, A. (1968) Isolation of leucocytes from human blood. A two phase system for removal of red cells with methylcellulose as erythrocyte-aggregating agent. Scand. J. Clin. Invest. 21 (suppl 97), 9-29.
9. Boyden, S. (1962) The chemotacic effect of mixtures of antibody and antigens on polymorphonuclear leukocytes. J. Exp. Med. 115, 456-466.

10. Merritt, J.E., McCarthy, S.A., Davies, M.P., Moores, K.E. (1990) Use of fuo-3 to measure cytoeolic $\mathrm{Ca}^{2+}$ in platelets and neutrophils: loading cells with the dye, calibration of traces, measurements in the presence of plasma, and buffering of cytosolic $\mathrm{Ca}^{2+}$. Biochem. J. 269, 513-519.

11. Daniels, R.H., Finnen, M.J., Hill, M.E., Lackie, J.M. (1992) Recombinant human monocyte IL-8 primes NADPH-oxidase and phospholipase $\mathbf{A}_{2}$ activation in human neutrophils. Immunology 75, 157-163.

12. Zigmond, S.H., Slonczewski, J.L., Wilde, M.W., Carson, M. (1988) Polymorphonuclear leukocyte locomotion is insensitive to lowered cytoplasmic calcium levels. Cell Motil. Cytoskeleton 9, 184-189.

13. Norgauer, J., Krutmann, J., Dobos, G.J., Traynor-Kaplan, A.E., Oades, Z.C., Schraufstatter, I.U. (1994) Actin polymerization, calcium-transients, and phospholipid metabolism in human neutrophils after stimulation with interleukin-8 and $N$-formyl peptide. J. Invest. Dermatol. 102, 310-314.

14. Rosof, P.M., Mohan C. (1992) Unidirectional, heterologous desensitization of the pertussis toxin receptor by the CD3/TCR complex. J. Immunol. 149, 3191-3199.

15. Hausdorf, W.P., Bouvier, M., O'Dowd, B.F., Irons, G.P. , Caron, M.C., Lefkowitz, R.J. (1989) Phosphorylation sites on two domains of the $\beta_{2}$-adrenergic receptor are involved in distinct pathways of receptor desensitization. J. Biol. Chem. 264, 12657-12665.

16. Clark, R.B., Kunkel, M.W., Friedman, J., Goka, T.J., Johnson, J.A. (1988) Activation of cAMP-dependent protein kinase is required for heterologous desensitization of adenylyl cyclase in S49 wild type cells. Proc. Nach. Acad. Sci. USA 85, 1442-1446.

17. Sibley, D.R., Strasser, R.H., Caron, M.C., Lekowitz, RJ. (1985) Homolagous desensitization of adenylate cyclase is associated with phosphorylation of the $\beta$-adrenergic receptor. J. Biol. Chem. 260, 3883-3886.

18. Ptasznik, A., Traynor-Kaplan, A., Bukoch, G.M. (1995) C protein-coupled chemoattractant receptors regulate Lyn tyrosine kinase. Shc adapter protein signaling complexes. J. Biol. Chem. 270, 19969-19973.

19. Vlahos, C.J., Matter, W.F., Brown, R.F., Traynor-Kaplan, A.E., Heyworth, P.G., Prosenitz, E.R., Ye, R.D., Mander, P., Schelm, J.A., Rothfuse, K.J. (1995) Investigation of neutrophil signal transduction using a specific inhibitor of phosphatidylinositol 3-kinase. J. Immunol. 154, 2413-2422.

20. Dobos, G.J., Norgauer, J., Eberle, M., Schollmeyer, PJ., Traynor-Kaplan, A.E. (1992) C5a reduces formyl peptide-induced actin polymerization and phosphatidylinositol $(3,4,5)$ trisphosphate formation, but not phosphatidylinositol $(4,5)$ bisphosphate hydrolysis and superoxide production, in human neutrophils. J. Immunol. 149, 609-614.

21. Metzner, B., Barbisch, M., Parlow, F., Kownatzki, E., Schraufstatter, I., Norgauer, J. (1995) Interleukin-8 and GRO alpha prime human neutrophils for superoxide anion production and induce up-regulation of $N$-formyl peptide receptors. J. Invest. Dermatol. 104, 789-791.

22. Johnson, S.E., Baglioni, C. (1988) Tumor necrosis factor receptors and cytocidal activity are downregulated by activators of protein kinase C.J. Biol. Chem. 263, 5686-5692.

23. Tsujimoto, M., Yip, Y.K., Vilcek, J. (1985) Tumor necrosis factor: specific binding and internalization in sensitive and resistant cells. Proc. Natl. Acad. Sci. USA 82, 7626-7630.

24. Heıderson, W.R., Chi, E.Y., Jorg, A., Klebanoff, SJ. (1983) Horse eosinophil degranulation induced by ionophore $\mathbf{A 2 3 1 8 7}$. Ultrastructure and role of phospholipase A2. Am. J. Pathol. 111, 342-349.

25. Murakami, M., Kudo, I., Suwa, Y., Inoue, K. (1992) Release of a 14-kDa group-II phospholipase A2 from activated mast cells and its poseible involvement in the regulation of the degranulation process. Eur. J. Biochem. 209, 257-265.

26. O'Rourke, A.M., Mescher, M.F., Apgar, J.R. (1992) IgE receptor-mediated arachidonic acid release by rat basophilic leukemia (RBL-2H3) cells: poesible role in activating degranulation. Mol. Immunol. 29, 1299-1308.

27. Forehand, J.R., Johnston, R.B., Bomalaski, J.S. (1993) Phospholipase $A_{2}$ activity in human neutrophils. Stimulation by lipopolysaccharide and posaible involvement in priming for an enhanced respiratory burst. J. Immunol. 151, 4918-25.

28. Tomhave, E.D., Richardson, R.M., Didsbury, J.R., Menard, L., Snyderman, R., Ali, H. (1994) Crose-desensitization of receptors for peptide chemattractants. J. Immunol. 153, 3267-3275. 